\title{
DNA-Based Herbal Teas' Authentication: An ITS2 and psbA-trnH Multi-Marker DNA Metabarcoding Approach
}

\author{
Jessica Frigerio $^{1}$, Giulia Agostinetto ${ }^{2}$, Valerio Mezzasalma ${ }^{1} \mathbb{D}$, Fabrizio De Mattia ${ }^{1}$, Massimo Labra ${ }^{2} \mathbb{D}$ \\ and Antonia Bruno $2, * \mathbb{D}$ \\ 1 FEM2-Ambiente, Piazza della Scienza 2, I-20126 Milano, Italy; jessica.frigerio@fem2ambiente.com (J.F.); \\ valerio.mezzasalma@fem2ambiente.com (V.M.); fabrizio.demattia@fem2ambiente.com (F.D.M.) \\ 2 Zooplantlab, Department of Biotechnology and Biosciences, University of Milano-Bicocca, Piazza della \\ Scienza 2, I-20126 Milano, Italy; g.agostinetto@campus.unimib.it (G.A.); massimo.labra@unimib.it (M.L.) \\ * Correspondence: antonia.bruno@unimib.it
}

Citation: Frigerio, J.; Agostinetto, G.; Mezzasalma, V.; De Mattia, F.; Labra, M.; Bruno, A. DNA-Based Herbal Teas' Authentication: An ITS2 and psbA-trnH Multi-Marker DNA Metabarcoding Approach. Plants 2021, 10, 2120. https://doi.org/ 10.3390/plants10102120

Academic Editor: Brent L. Nielsen

Received: 31 July 2021

Accepted: 25 September 2021

Published: 6 October 2021

Publisher's Note: MDPI stays neutral with regard to jurisdictional claims in published maps and institutional affiliations.

Copyright: (c) 2021 by the authors. Licensee MDPI, Basel, Switzerland. This article is an open access article distributed under the terms and conditions of the Creative Commons Attribution (CC BY) license (https:/ / creativecommons.org/licenses/by/ $4.0 /)$.

\begin{abstract}
Medicinal plants have been widely used in traditional medicine due to their therapeutic properties. Although they are mostly used as herbal infusion and tincture, employment as ingredients of food supplements is increasing. However, fraud and adulteration are widespread issues. In our study, we aimed at evaluating DNA metabarcoding as a tool to identify product composition. In order to accomplish this, we analyzed fifteen commercial products with DNA metabarcoding, using two barcode regions: $p s b A$-trnH and ITS2. Results showed that on average, 70\% (44-100) of the declared ingredients have been identified. The ITS2 marker appears to identify more species $(n=60)$ than psbA-trnH $(n=35)$, with an ingredients' identification rate of $52 \%$ versus $45 \%$, respectively. Some species are identified only by one marker rather than the other. Additionally, in order to evaluate the quantitative ability of high-throughput sequencing (HTS) to compare the plant component to the corresponding assigned sequences, in the laboratory, we created six mock mixtures of plants starting both from biomass and gDNA. Our analysis also supports the application of DNA metabarcoding for a relative quantitative analysis. These results move towards the application of HTS analysis for studying the composition of herbal teas for medicinal plants' traceability and quality control.
\end{abstract}

Keywords: DNA barcoding; DNA metabarcoding; HTS; herbal teas; food fraud; ITS2; $p s b$-trnH

\section{Introduction}

Medicinal plants have been used in traditional medicine for centuries due to their therapeutic properties. Although they are mostly consumed as herbal infusions and tinctures, employment as ingredients of herbal and food supplements is increasing worldwide [1]. Consumers' awareness about healthy diets and their benefits is expanding the botanicals and herbal supplements market [1]. In the United States, the market of herbal supplements is worth over US\$7.4 billion per year [2], and the EU market accounts for a value of EUR€ 1.8 billion [3]. Despite this, fraud and adulteration are widespread issues in the herbal and food industry [4]. Medicinal plants are usually sold as herbal tea or as an ingredient, and fraud and adulteration are difficult to identify [5]. The substitution of high-value plants with cheaper ones has been widely reported in the literature [6-8]. Moreover, adulteration with toxic plants has also been recorded and may lead to severe health risks [9,10]. These compounds are in high concentration in plants that can be accidentally used in herbal teas [11]. The authenticity of herbal teas can affect the safety of the product and indirectly, the consumers' trust. Detecting adulteration and identifying the botanical species present in herbal mixtures is fundamental to guarantee the consumers' safety. Multiple methods, mainly based on morphological and chemical characterization, have been proposed in plant pharmacopoeia. However, these methods fail when the morphological features are lost or when the chemical profiles are shared among congenerics [12]. To identify and confirm the raw ingredients of processed herbal products, quality control involving standard processes 
can be used to identify specific targeted compounds, but could not detect other non-target plant constituents in herbal samples.

In the last decade, the use of molecular tools for the authentication of food products has drastically increased $[13,14]$. In this context, the biomolecular analysis of DNA barcoding has become more and more important over time [15]. Although food authentication using DNA barcoding is well-supported and validated when used to identify single species [16-18], the characterization of plant complex mixtures and/or processed products is still a challenge. DNA could undergo degradation processes due to industrial treatments. As a consequence, in several processed foods, DNA could be highly degraded and fragmented [19]. To analyze these complex matrices, the DNA barcoding approach was combined with high-throughput DNA-sequencing technologies (HTS), which offers the opportunity to simultaneously sequencing multiple DNA amplicons (DNA metabarcoding) [20]. Nevertheless, DNA metabarcoding still has some limitations, such as amplification biases, accidental laboratory contamination when DNA is in low concentration and the difficulty of ingredients' quantification $[19,21,22]$. In our study, we wanted to (i) evaluate if DNA metabarcoding can be a universal and sensitive tool to identify all the species in a product. To accomplish this, we analyzed fifteen commercial products with DNA metabarcoding, focusing on two barcode regions: the nuclear ITS2 and, for the very first time (in a DNA metabarcoding context), to the best of our knowledge, the plastidial intergenic spacer $p s b$-trnH. Additionally, in order to (ii) evaluate the quantitative ability of HTS, we compared the declared occurrence and abundance of plant components in herbal products to the corresponding assigned sequences, creating six mock mixtures of plants in the laboratory starting both from raw plants (biomass) and genomic DNA (gDNA).

\section{Results}

\subsection{DNA Metabarcoding Characterization of Commercial Herbal Teas}

HTS analysis produced about $12,358,533$ raw pair reads from the analyzed samples, with an average of $111,338.13$ reads per sample $(S D=61,835.85)$. After quality filtering, merging reads, chimaera removal and clustering, we obtained a total of 508 ITS2 and 235 psbA-trnH OTUs. Negative controls for library sequencing were not included in the analysis due to the very low amount of DNA reads. Overall, a total of 83 taxa were identified, of which 35 were found only by the $p s b$-trnH marker and 60 by the ITS2 marker. Considering the species declared on the label, only 12 species out of 53 were identified by both markers (Arctium lappa, Arnica montana, Betula sp., Camellia sinensis, Glycyrrhiza glabra, Ilex paraguariensis, Matricaria chamomilla, Melissa officinalis, Passiflora incarnata, Paullinia cupana, Raphanus sativus and Senna alexandrina) (Figures 1 and 2 and Table 1).

Most of the OTUs were assigned to the species taxonomic level, however, in some genera, such as Mentha, the low interspecific variability did not allow the species to be identified. On average, 70\% (44-100) of the declared ingredients have been identified in the analyzed products (see Table 1). Some products belonging to the same companies (see Table 2) have a higher rate of ingredient identification (e.g., company 5, $n=100 \%$ ) than others (e.g., company 3, $n=44 \%$ ), as can be seen in Figure 3.

Overall, our data reported a mixed composition reflecting, at least in part, the complexity in terms of detected species of the herbal teas. DNA metabarcoding results allowed the detection of the declared species in most of the cases. In all samples, except for HT_013, it allowed the detection of undeclared elements. For example, in the HT_001 sample, we found a high percentage (17\%) of Pimpinella anisum, a plant typically used in herbal teas but not declared on the label. In the sample HT_002, coming from the same company of sample HT_001 (Company 1), the presence of Pimpinella anisum is declared on the label and we found the presence of this ingredient. Additionally, in the HT_012 sample, a high percentage $(21 \%)$ of a species commonly used for botanicals, Melilotus officinalis, was found. 


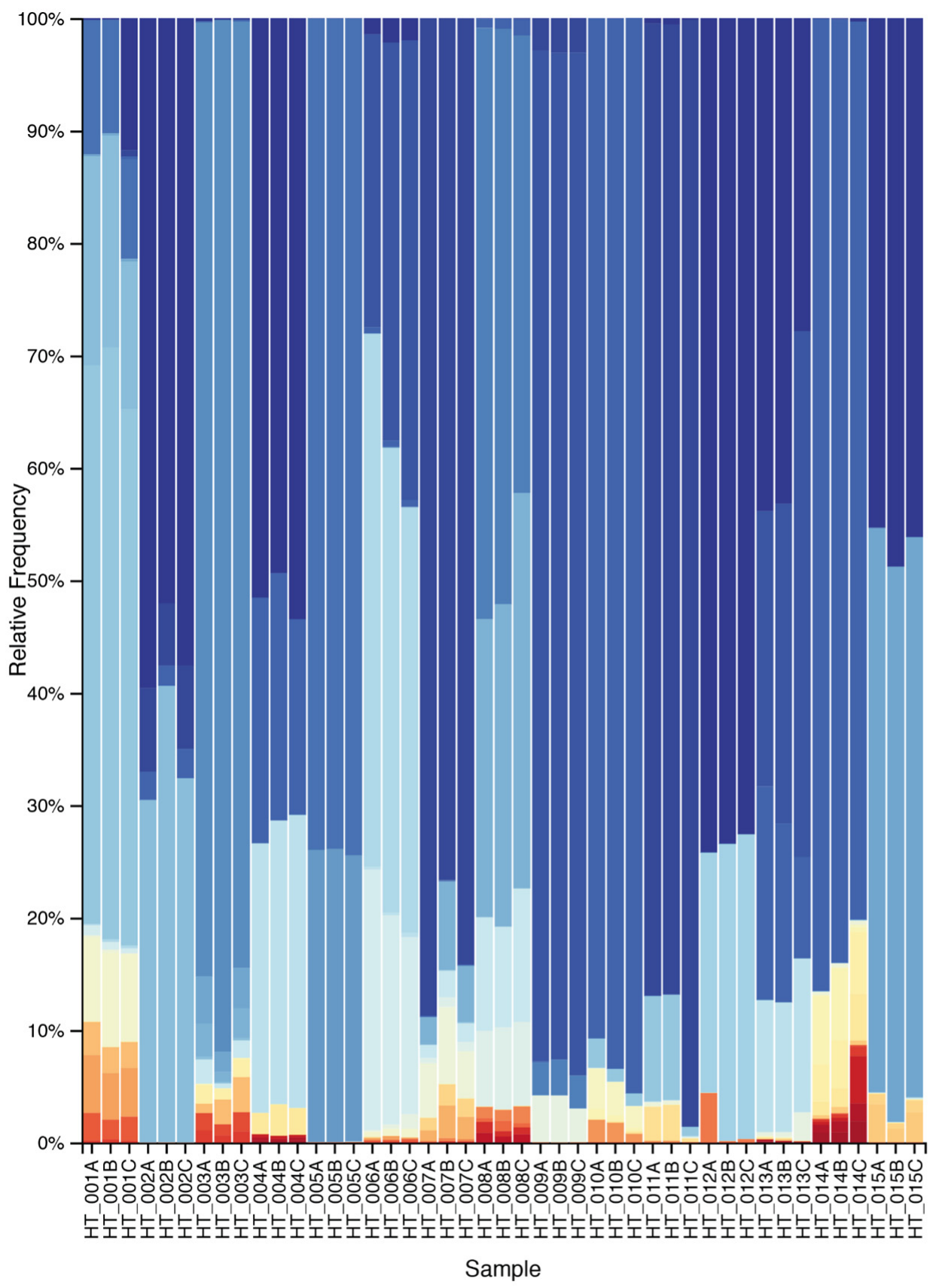

\section{Legend}

Foeniculum vulgare

Glycyrrhiza glabra

Malva sylvestris

Matricaria chamomilla

Althaea officinalis

Zingiber officinale

Betula sp.

Echinacea angustifolia

Filipendula ulmaria

Camellia sinensis

Pimpinella anisum

Melissa officinalis

Carum carvi

Urtica dioica

Senna alexandrina

Polyspora sp.

Taraxacum officinale

Ipomoea sp.

Malva sp.

Convolvulus arvensis

Arctium lappa

Raphanus sativus

Passiflora incarnata

Tilia plathyphyllos

Capsella bursa-pastoris

Lavandula sp.

Amaranthus viridis
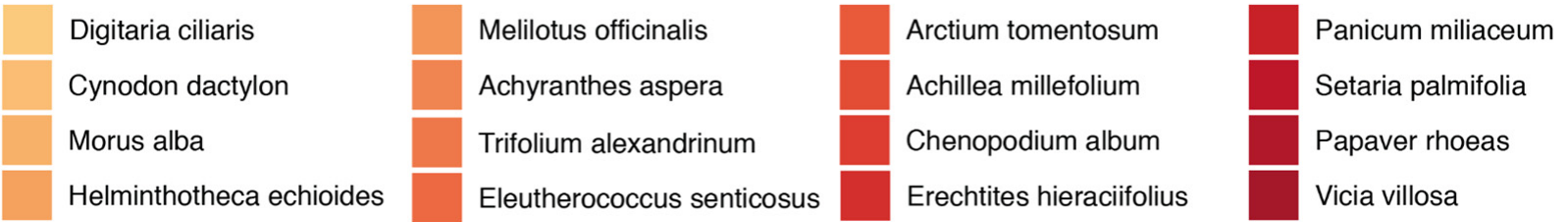

Figure 1. Relative abundance of the plant taxa recovered in the 15 herbal tea products through ITS2 metabarcoding sequencing. Only the taxa present in at least two of the three replicas and in a concentration $>1 \%$ are shown. The complete list of taxa is reported in Supplementary Table S1. 


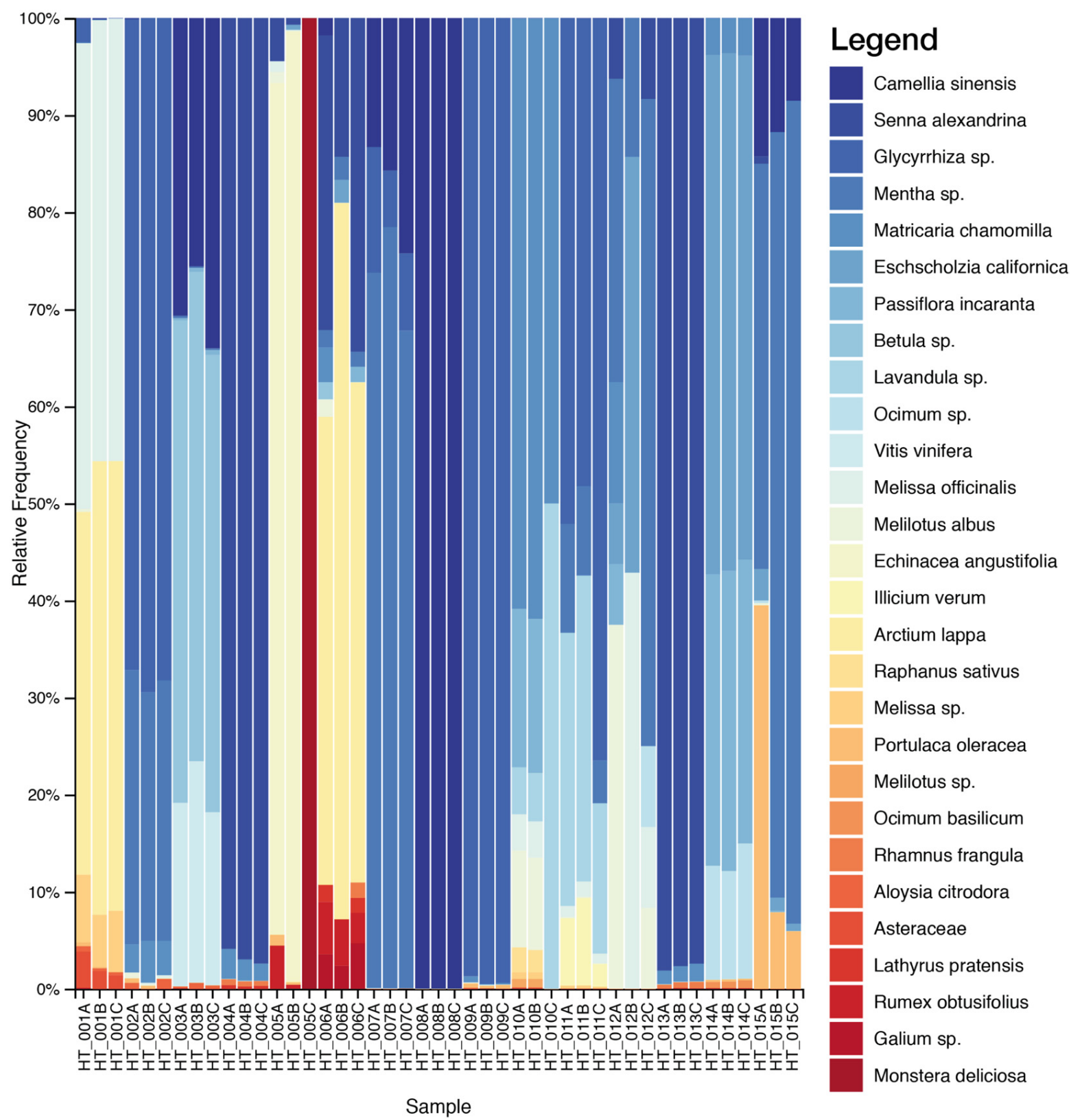

Figure 2. Relative abundance of the plant taxa recovered in the 15 herbal tea products through $p s b$-trnH metabarcoding sequencing. Only the taxa present in at least two of the three replicas and in a concentration $>1 \%$ are shown. The complete list of taxa is reported in Supplementary Table S1.

Table 1. List of the detected ingredients in market samples, based on DNA metabarcoding assignment. For each sample, the declared species, assigned species for the DNA barcode marker $p s b A$-trnH and ITS 2 and the company are indicated. The percentage values refer to the relative abundance of HTS sequences for each recognized ingredient. Percentage and plants (indicated as scientific or common name) of declared species are reported as indicated in the commercial label. The chosen taxa in the table were present in at least two out of three replicates.

\begin{tabular}{|c|c|c|c|}
\hline ID LAB & Declared Species & $\begin{array}{l}\text { Assigned Species } \\
\text { (psbA-trnH) }\end{array}$ & Assigned Species (ITS2) \\
\hline HT_001 & $\begin{array}{c}\text { Agropyron repens Beauv. } 20 \% \text {, } \\
\text { Taraxacum officinale Weber } 20 \% \text {, } \\
\text { Arctium Iappa } 15 \% \text {, Cichorium intybus } \\
\text { 15\%, Melissa officinalis } 15 \% \text {, Cynara } \\
\text { scolymus } 15 \%\end{array}$ & $\begin{array}{c}\text { Melissa officinalis } 52 \% \text {, Arctium lappa } \\
46 \% \text {, Reichardia ligulata } 2 \%\end{array}$ & $\begin{array}{l}\text { Melissa officinalis } 51 \% \text {, Pimpinella } \\
\text { anisum } 17 \% \text {, Althaea officinalis } 10 \% \text {, } \\
\text { Arctium lappa } 8 \% \text {, Helminthotheca } \\
\text { echioides } 4 \% \text {, Arctium tomentosum } 2 \% \text {, } \\
\text { Cynodon dactylon } 2 \% \text {, Taraxacum } \\
\text { officinale } 3 \% \text {, Asteraceae } 2 \%\end{array}$ \\
\hline
\end{tabular}


Table 1. Cont

\begin{tabular}{|c|c|c|c|}
\hline ID LAB & Declared Species & $\begin{array}{l}\text { Assigned Species } \\
\quad(p s b A-t r n H)\end{array}$ & Assigned Species (ITS2) \\
\hline HT_002 & $\begin{array}{c}\text { Foeniculum vulgare } 20 \% \text {, Glycyrrhiza } \\
\text { glabra } 20 \% \text {, Pimpinella anisum } 20 \% \text {, } \\
\text { Mentha piperita } 20 \% \text {, Citrus sinensis } \\
\text { var. dulcis } 15 \% \text {, Matricaria chamomilla } \\
5 \%\end{array}$ & $\begin{array}{c}\text { Glycyrrhiza sp. } 69 \% \text {, Mentha sp. } 26 \% \text {, } \\
\text { Matricaria chamomilla } 4 \% \text {, Aloysia } \\
\text { citrodora } 1 \%\end{array}$ & $\begin{array}{c}\text { Foeniculum vulgare } 54 \% \text {, Pimpinella } \\
\text { anisum } 37 \% \text {, Glycyrrhiza glabra } 7 \% \text {, } \\
\text { Matricaria chamomilla } 2 \%\end{array}$ \\
\hline HT_003 & $\begin{array}{c}\text { Camelia sinensis } 20 \% \text {, Prunus cerasus } \\
20 \% \text {, Citrus limon } 20 \% \text {, Betula } \\
\text { pendula } 15 \% \text {, Agropyron Repens } 15 \% \text {, } \\
\text { Vitis vinifera } 10 \%\end{array}$ & $\begin{array}{c}\text { Betula sp. } 49 \% \text {, Camellia sinensis } 30 \% \text {, } \\
\text { Vitis vinifera } 21 \%\end{array}$ & $\begin{array}{c}\text { Betula sp. } 89 \% \text {, Camellia sinensis } 2 \% \text {, } \\
\text { Chenopodium album } 1 \% \text {, Cynodon } \\
\text { dactylon } 2 \% \text {, Filipendula ulmaria } 3 \% \text {, } \\
\text { Achillea millefolium } 1 \% \text {, Polyspora } \\
\text { axillaris } 1 \% \text {, Tilia platyphyllos } 1 \%\end{array}$ \\
\hline HT_004 & $\begin{array}{c}\text { Senna alexandrina } 40 \% \text {, Rhamnus } \\
\text { frangula } 20 \% \text {, Matricaria chamomilla, } \\
\text { Foeniculum vulgare }\end{array}$ & $\begin{array}{c}\text { Senna alexandrina } 97 \% \text {, Rhamnus } \\
\text { frangula } 1 \% \text {, Matricaria } \\
\text { chamomilla } 2 \%\end{array}$ & $\begin{array}{l}\text { Foeniculum vulgare } 52 \% \text {, Matricaria } \\
\text { chamomilla } 22 \% \text {, Senna alexandrina } \\
24 \% \text {, Capsella bursa-pastoris } 2 \%\end{array}$ \\
\hline HT_005 & $\begin{array}{c}\text { Echinacea angustifolia } 30 \% \text {, Citrus } x \\
\text { limon, Althaea officinalis, Rosa canina, } \\
\text { Hibiscus sabdariffa, Sambucus nigra } \\
10 \%\end{array}$ & $\begin{array}{c}\text { Echinacea angustifolia } 94 \%, \text { Monstera } \\
\text { deliciosa } 4 \% \text {, Portulaca oleracea } 1 \% \text {, } \\
\text { Rumex obtusifolius } 1 \%\end{array}$ & $\begin{array}{c}\text { Althaea officinalis } 74 \% \text {, Echinacea } \\
\text { angustifolia } 26 \%\end{array}$ \\
\hline HT_006 & $\begin{array}{c}\text { Urtica dioica } 30 \% \text {, Arctium lappa } 20 \% \text {, } \\
\text { Taraxacum officinale, Citrus x limon, } \\
\text { Malva officinalis }\end{array}$ & $\begin{array}{c}\text { Arctium lappa } 62 \% \text {, Senna alexandrina } \\
24 \% \text {, Galium sp. } 4 \% \text {, Lathyrus } \\
\text { pratensis } 2 \% \text {, Mentha sp. } 4 \% \text {, Rumex } \\
\text { obtusifolius } 4 \%\end{array}$ & $\begin{array}{l}\text { Urtica dioica } 43 \% \text {, Malva sp. } 35 \% \text {, } \\
\text { Taraxacum officinale 19\%, Foeniculum } \\
\text { vulgare } 2 \% \text {, Matricaria chamomilla } 1 \%\end{array}$ \\
\hline HT_007 & $\begin{array}{c}\text { Camellia sinensis } 51 \% \text {, Mentha } 29 \% \text {, } \\
\text { Glycyrrhiza glabra } 8.25 \% \text {, Mentha } \\
\text { piperita } 3.9 \% \text {, Aloe vera }\end{array}$ & $\begin{array}{c}\text { Mentha sp. } 74 \% \text {, Camellia sinensis } \\
\text { 17\%, Glycyrrhiza sp. } 9 \%\end{array}$ & $\begin{array}{c}\text { Glycyrrhiza glabra } 84 \% \text {, Amaranthus } \\
\text { viridis } 2 \% \text {, Camellia sinensis } 5 \% \text {, } \\
\text { Convolvulus arvensis } 5 \% \text {, Ipomoea sp. } \\
1 \% \text {, Morus alba } 2 \% \text {, Polyspora axillaris } \\
1 \%\end{array}$ \\
\hline HT_008 & $\begin{array}{c}\text { Camellia sinensis } 62.9 \% \text {, Zingiber } \\
\text { officinalis } 22 \% \text {, Peach } 1 \% \text {, Ginseng } \\
1 \% \text {, Aloe vera }\end{array}$ & Camelia sinensis $100 \%$ & $\begin{array}{c}\text { Camellia sinensis } 30 \% \text {, Zingiber } \\
\text { officinale } 23 \% \text {, Eleutherococcus } \\
\text { senticosus } 1 \% \text {, Ocimum sp. } 25 \% \text {, } \\
\text { Polyspora sp. } 10 \% \text {, Ipomoea sp. } 7 \% \text {, } \\
\text { Achyranthes aspera } 1 \% \text {, Erechtites } \\
\text { hieraciifolius } 1 \% \text {, Setaria palmifolia } 1 \%\end{array}$ \\
\hline HT_009 & $\begin{array}{c}\text { Zingiber officinale, Citrus limon, } \\
\text { Malva sylvestris, Cymbopogon citratus, } \\
\text { Glycyrrhiza glabra }\end{array}$ & Glycyrrhiza sp. $100 \%$ & $\begin{array}{c}\text { Malva sylvestris } 94 \% \text {, Glycyrrhiza } \\
\text { glabra } 3 \% \text {, Ocimum sp. } 2 \% \text {, Zingiber } \\
\text { officinale } 1 \%\end{array}$ \\
\hline HT_010 & $\begin{array}{c}\text { Matricaria chamomilla } 44.4 \% \text {, Melissa } \\
\text { officinalis } 22.2 \% \text {, Betula } \\
\text { pendula/pubescens, Passiflora } \\
\text { incarnata, Lavandula officinalis } 5.6 \%\end{array}$ & $\begin{array}{c}\text { Matricaria chamomilla 51\%, Lavandula } \\
\text { sp. } 14 \% \text {, Melilotus sp. 11\%, Melissa } \\
\text { officinalis 6\%, Passiflora incarnata } \\
16 \% \text {, Raphanus sativus } 2 \%\end{array}$ & $\begin{array}{c}\text { Matricaria chamomilla } 93 \% \text {, Melilotus } \\
\text { officinalis 1\%, Melissa officinalis } 2 \% \text {, } \\
\text { Passiflora incarnata } 1 \% \text {, Raphanus } \\
\text { satious 3\% }\end{array}$ \\
\hline HT_011 & $\begin{array}{c}\text { Illicium verum } 27 \% \text {, Mentha piperita } \\
25 \% \text {, Melissa officinalis, Glycyrrhiza } \\
\text { glabra, Lavandula officinalis, Cinchona } \\
\text { officinalis, Gentiana lutea } 2 \% .\end{array}$ & $\begin{array}{l}\text { Glycyrrhiza sp. } 60 \% \text {, Lavandula sp. } \\
25 \% \text {, Mentha sp. } 7 \% \text {, Illicium verum } \\
7 \% \text {, Melissa officinalis } 1 \%\end{array}$ & $\begin{array}{l}\text { Glycyrrhiza glabra } 90 \% \text {, Melissa } \\
\text { officinalis } 8 \% \text {, Lavandula sp. } 2 \%\end{array}$ \\
\hline HT_012 & $\begin{array}{c}\text { Foeniculum vulgare } 40 \% \text {, Illicium } \\
\text { verum } 40 \% \text {, Carum carvi, Mentha } \\
\text { piperita } 9 \%\end{array}$ & $\begin{array}{c}\text { Mentha sp. } 41 \% \text {, Eschscholzia } \\
\text { californica } 20 \% \text {, Melilotus sp. } 21 \% \text {, } \\
\text { Melissa officinalis } 18 \%\end{array}$ & $\begin{array}{c}\text { Foeniculum vulgare } 72 \% \text {, Carum carvi } \\
27 \% \text {, Trifolium alexandrinum } 1 \%\end{array}$ \\
\hline HT_013 & $\begin{array}{c}\text { Senna alexandrina } 40 \% \text {, Rhamnus } \\
\text { frangula } 15 \% \text {, Matricaria chamomilla } \\
15 \% \text {, Foeniculum vulgare } 15 \% \text {, Malva } \\
\text { officinalis } 15 \%\end{array}$ & $\begin{array}{c}\text { Senna alexandrina } 98 \% \text {, Rhamnus } \\
\text { frangula } 1 \% \text {, Matricaria chamomilla } \\
1 \%\end{array}$ & $\begin{array}{c}\text { Foeniculum vulgare } 38 \% \text {, Malva sp. } \\
\text { 34\%, Matricaria chamomilla } 16 \% \text {, } \\
\text { Senna alexandrina } 12 \%\end{array}$ \\
\hline HT_014 & $\begin{array}{c}\text { Passiflora incarnata, Eschscholzia } \\
\text { californica Cham., Matricaria } \\
\text { chamomilla, Tilia platyphyllos, } \\
\text { Ocimum basilicum }\end{array}$ & $\begin{array}{c}\text { Eschscholzia californica } 53 \% \text {, Passiflora } \\
\text { incarnata } 30 \% \text {, Matricaria chamomilla } \\
4 \% \text {, Ocimum sp. } 13 \%\end{array}$ & $\begin{array}{l}\text { Matricaria chamomilla } 83 \% \text {, Passiflora } \\
\text { incarnata } 7 \% \text {, Panicum miliaceum } 2 \% \text {, } \\
\text { Papaver rhoeas } 1 \% \text {, Tilia sp. } 4 \% \text {, Vicia } \\
\text { villosa } 1 \% \text {, Capsella bursa-pastoris } 2 \%\end{array}$ \\
\hline HT_015 & $\begin{array}{l}\text { Camellia sinensis, Filipendula ulmaria, } \\
\text { Foeniculum vulgare, Mentha spicata }\end{array}$ & $\begin{array}{c}\text { Mentha sp. } 69 \% \text {, Portulaca oleracea } \\
\text { 17\%, Camellia sinensis } 12 \%, \\
\text { Eschscholzia californica } 2 \%\end{array}$ & $\begin{array}{c}\text { Filipendula ulmaria } 50 \% \text {, Foeniculum } \\
\text { vulgare } 47 \% \text {, Digitaria ciliaris } 2 \%\end{array}$ \\
\hline
\end{tabular}

Common infesting herbaceous species, such as Cynodon dactylon, Helminthotheca echioides, Chenopodium album, Digitaria ciliaris and Lathyrus pratensis, were found in several samples in a percentage range of $2-5 \%$. The presence of such plants could be harmful, as some species could be poisonous [9] or cause allergies [23]. 
Table 2. The ID specimen for all samples, the company of production and the sample typology.

\begin{tabular}{ccc}
\hline ID LAB & Company & Sample Typology \\
\hline HT_001 & Company 1 & Purifying Herbal Tea \\
HT_002 & Company 1 & Digestive Herbal Tea \\
HT_003 & Company 1 & Slimming Herbal Tea \\
HT_004 & Company 2 & Laxative Herbal Tea \\
HT_005 & Company 2 & Aromatic Herbal Tea \\
HT_006 & Company 2 & Purifying Herbal Tea \\
HT_007 & Company 3 & Aromatic Herbal Tea \\
HT_008 & Company 3 & Aromatic Herbal Tea \\
HT_009 & Company 3 & Depurative Herbal Tea \\
HT_010 & Company 4 & Relaxing Herbal Tea \\
HT_011 & Company 4 & Digestion Herbal Tea \\
HT_012 & Company 4 & Flat Stomach Herbal Tea \\
HT_013 & Company 5 & Laxative Herbal Tea \\
HT_014 & Company 5 & Sleep Herbal Tea \\
HT_015 & Company 5 & Draining Herbal Tea \\
\hline
\end{tabular}
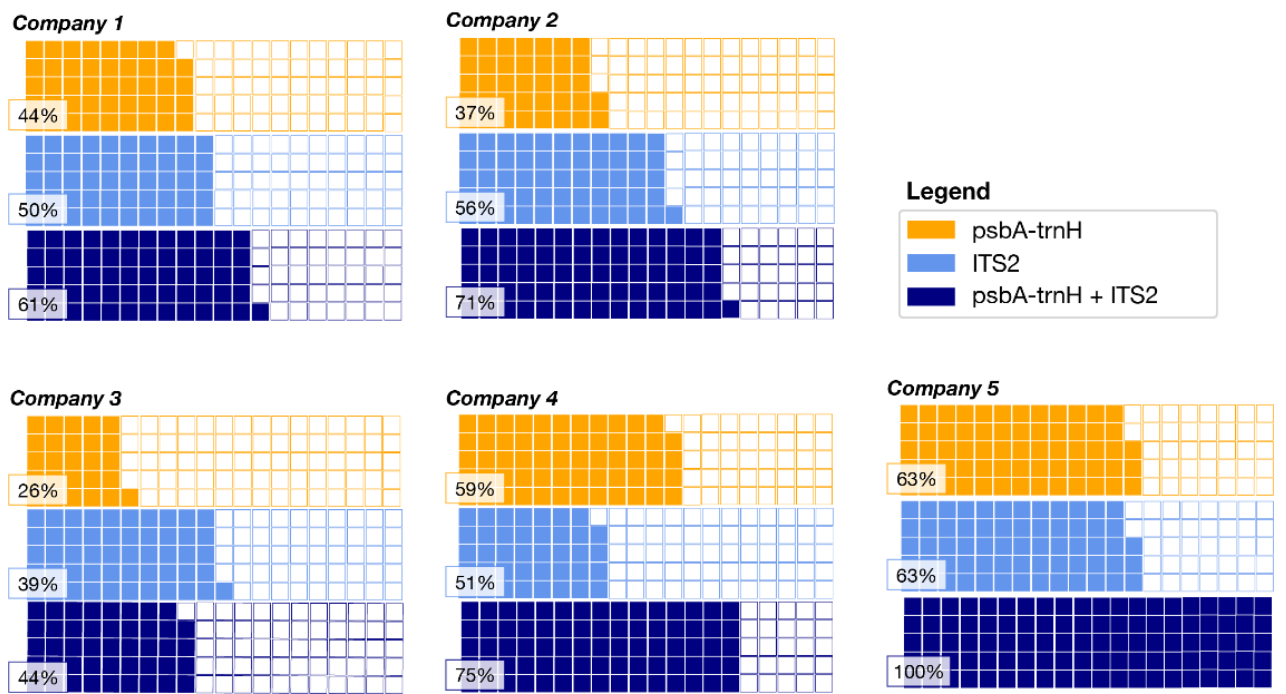

Figure 3. The waffle chart shows, in orange, the percentage of assigned taxa declared in the label for the barcode marker $p s b$-trnH, in light blue, the percentage of assigned taxa declared in the label for the barcode marker ITS2, and in blue, the total percentage using both markers for all the companies. The percentages of assigned taxa are reported in Supplementary Table S1.

The ITS2 marker appears to identify more species $(n=60)$ than $p s b A-t r n H(n=35)$, with an ingredient identification rate of $52 \%$ (39-63) for ITS2 versus $45 \%$ (26-63) for $p s b A-t r n H$. However, the use of both markers has made it possible to almost double the capacity for identifying and assigning species, for some samples (HT_013-HT_015) reaching $100 \%$ identification of the declared species on the label. Only 12 species declared on the label have been identified by both markers. It has been noticed that some species are identified only by one marker rather than the other. Specifically, Eschscholzia californica, Mentha sp., Vitis vinifera, Illicium verum and Rhamnus frangula were identified only with the $p s b A-t r n H$ marker, while the species Althaea officinalis, Epilobium angustifolium, Foeniculum vulgare, Malva sp., Pimpinella anisum, Solidago virgaurea, Taraxacum officinale, Urtica dioica and Zingiber officinale were identified only with the ITS2 marker. This result appears to be reproducible considering different samples from different companies. Furthermore, it was also confirmed by the fact that Althaea officinalis and Solidago virgaurea species were present in the mock created in the laboratory and were never recognized by the $p s b A-t r n H$ marker. In order to exclude the failure in ingredient identification due to a lack 
in the database, for each species, the presence of sequences deposited in the NCBI database (https:/ / www.ncbi.nlm.nih.gov/ accessed on 7 September 2021) was confirmed.

\subsection{DNA Metabarcoding for Mock Mixtures' Quantification}

As shown in Figure 4, by analyzing both DNA barcode regions (i.e., $p s b A$-trnH and ITS2), we were able to identify and correctly assign each plant used for the mock mixtures' preparation. Nevertheless, through the analysis of the barcode region $p s b A-\operatorname{trn} H$, we were not able to identify the species Althaea officinalis and Solidago virgaurea, both in the biomass mixtures and in the genomic DNA mixtures. To confirm this phenomenon, DNA amplification of both species was carried out using both primer pairs ( $p s b A$-trnH and ITS2). Amplicons were correctly visualized on agarose gel, sequenced and assigned to the species Althaea officinalis and Solidago virgaurea. Similarly, with the analysis of the ITS2 barcode region, we did not find the species Paullinia cupana in the mock mixtures created from the raw plant (biomass). This was probably due to the low yield of genomic DNA (see Supplementary Table S2). Since Paullinia cupana was detected in the gDNA mixtures, this result confirms the bias due to the DNA extraction phase.

Table 3. The percentages of the plants used for the mock mixture creation. Samples QB_016, QB_017 and QB_018 were created starting from the biomasses of raw plants, and samples QG_019, QG_020 and QG_021 were created starting from the genomic DNA.

\begin{tabular}{cccccccc}
\hline Species & Plant Section & QB_016 & QB_017 & QB_018 & QG_019 & QG_020 & QG_021 \\
\hline Althaea officinalis & Roots & $20 \%$ & $6 \%$ & $35 \%$ & $20 \%$ & $6 \%$ & $35 \%$ \\
Arnica montana & Flowers & $20 \%$ & $6 \%$ & $6 \%$ & $20 \%$ & $6 \%$ & $6 \%$ \\
Ilex paraguariensis & Leaves & $20 \%$ & $76 \%$ & $20 \%$ & $20 \%$ & $76 \%$ & $20 \%$ \\
Paullinia cupana & Seeds & $20 \%$ & $6 \%$ & $30 \%$ & $20 \%$ & $6 \%$ & $30 \%$ \\
Solidago virgaurea & Aerial parts & $20 \%$ & $6 \%$ & $9 \%$ & $20 \%$ & $6 \%$ & $9 \%$ \\
\hline
\end{tabular}
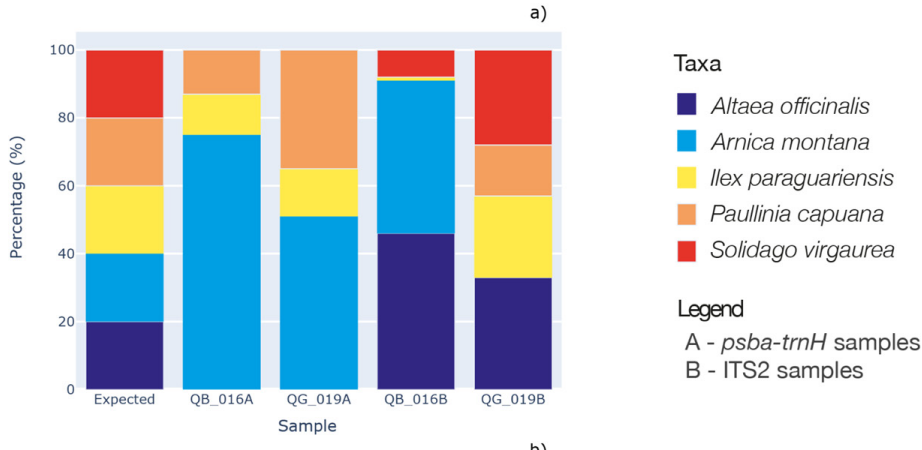

c)
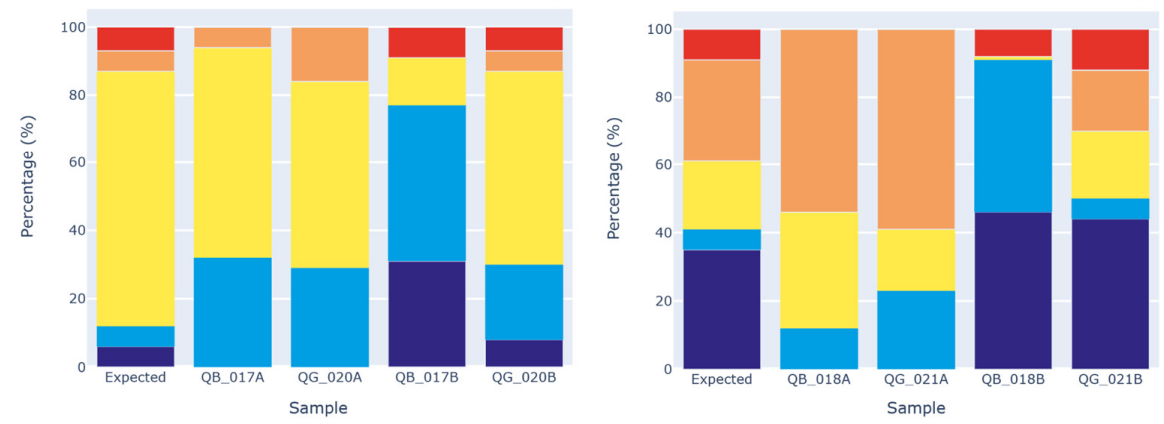

Figure 4. Graphs showing the expected percentages and the percentages obtained after HTS sequencing for the $p s b A$-trnH and ITS2 barcode markers both for the mock mixtures created starting from biomasses and genomic DNA. The three different mixture concentrations are shown in $(\mathbf{a}-\mathbf{c})$ panels (see Table 3 for detailed composition). For each panel, Expected: expected composition, QB_A: $p s b A$ trnH biomasses, QG_A: $p s b A$-trnH gDNA, QB_B: ITS2 biomasses, QG_B: ITS2 gDNA. Percentages are shown in Supplementary Table S3. 
To determine which mixture strategy (gDNA or biomass) better approximates the expected sample composition, a PCoA analysis with Bray-Curtis distance was performed. As shown in Figure 5, gDNA samples (blue points) appear to be closer to the samples representing the expected composition (in yellow), compared to the mock mixture obtained starting from the raw plants (in red), considering their composition obtained both with $p s b A$-trnH and ITS2. To test the difference between the biomass mock mixtures, the gDNA mixtures and the expected composition samples, a PERMANOVA analysis was carried out.

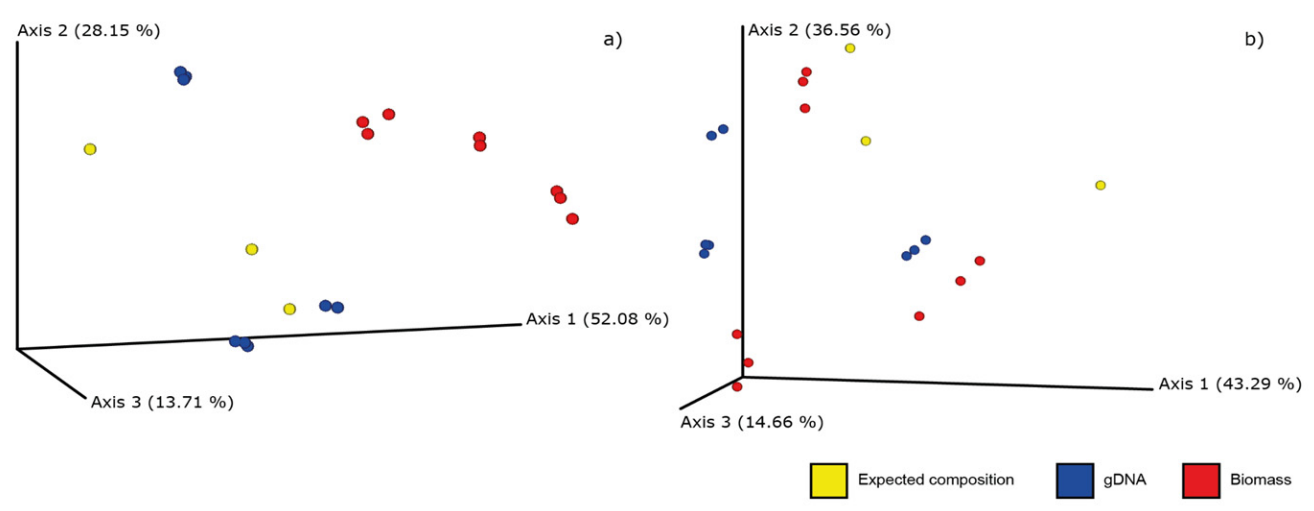

Figure 5. In the PCoA graphs, the yellow dots represent the expected composition samples, the red ones indicate the mock mixtures created starting from the raw plants and the blue ones indicate the mock mixtures obtained from genomic DNA. (a) PCoA representation considering ITS2 analysis, while (b) psbA-trnH analysis.

Considering the ITS2 barcode, the comparison between the gDNA group and the expected composition samples group reported no significant differences in composition ( $q$-value $=0.86$ ), while both the comparison between biomass mixture and the expected ones and the biomass mixture and the gDNA group resulted in a significant difference (q-value $=0.012$ and 0.003, respectively). Considering the $p s b A$-trnH analysis, instead, we observed that gDNA and biomass mixture do not significantly differ (q-value $=0.64$ ), while the comparison of the expected composition group versus biomass and gDNA groups reported a q-value $=0.06$ and 0.028 , respectively. All the results are available in Supplementary Tables S4 and S5.

\section{Discussion}

Obtaining a representative assessment of complex herbal mixtures is influenced by many factors, including the quality and type of raw material, DNA extraction yield, the DNA barcode(s) choice and a complete reference database [24]. In this study, we took into account these issues, applying a workflow suited to reach the identification of the composition of plant-based processed products.

\subsection{A Multi-Marker Approach}

It is now well-documented that in plants, no single DNA region provides suitable levels of species' discrimination. The CBOL Plant Working Group (2009) suggest to use two core plastid DNA barcodes, targeting part of the genes rbcL and matK for DNA barcoding [25], often together with a portion of the more variable internal transcribed spacers of nuclear ribosomal DNA (ITS2) [26-28], or the plastid intergenic spacer $p s b A$ $\operatorname{trnH}[29]$.

For this reason, we decided to adopt a multi-marker approach to identify herbal tea composition. Previous studies have used a multi-marker approach for mesozooplankton DNA analysis [30], for dietary analysis of animals [31] and for traditional medicine [32]. As plants have low intraspecific variability, the use of more than one DNA barcoding marker increases the chance of identifying ingredients at the species level. Our analyses confirmed our hypothesis. Considering for instance the sample HT_007, by only using psbA-trnH, we 
were able to assign the genus Glycyrrhiza sp., but with the addition of the ITS2 marker, we were able to reach the species level of Glycyrrhiza glabra. Additionally, our result showed that $p s b A-t r n H$ and ITS2 markers have a complementary output, with 12 shared taxa identified, but 5 and 9 unique taxa for $p s b A$-trnH and ITS2, respectively. A similar result was shown by Arulandhu and colleagues [32], who demonstrated that a multi-marker approach increases the resolution and the quality of the results. It is noteworthy that, even in the mock communities, created ad hoc (known in composition), the differential identification capacity of the two markers was observed. This is not due to the absence of the corresponding sequences in the database: for almost all the species under analysis and for both markers, we checked NCBI database completeness, and for species where the sequence deposited in the database was not present, as in the case of Paullinia cupana, we used sequences from our private databases. Thus, these results could suggest that marker choice can significantly affect the outputs. For example, it has already been reported in the literature that primers have a differential affinity for some species, leading to preferential amplification of some taxa, and substantial differences in selectivity among different primers $[22,33,34]$. Nevertheless, further studies are needed to verify whether this phenomenon is reproducible.

ITS2 marker analysis allowed us to identify a greater number of taxa compared to psbA-trnH (60 versus 35). Nevertheless, several species, such as Melissa officinalis, Arctium lappa, Matricaria chamomilla, Camellia sinensis, Senna alexandrina and Glycyrrhiza glabra, were identified by both markers in all samples where they were declared on the label.

This result could be due to the type of sample matrix (such as different parts of a plant or different industrial processing steps) or to the taxa present in the sample analyzed. Ya-Na and colleagues assessed the identification ability of ITS2 and $p s b A$-trnH for members of the Apocynaceae family [35]. They reported that ITS2 showed a high identification efficiency of $97 \%$ and $100 \%$ of the samples at the species and genus levels respectively, and $p s b A-t r n H$ successfully identified $95 \%$ and $100 \%$ of the samples at the species and genus levels, respectively. It is noteworthy that the barcode combination of ITS2/psbAtrn $\mathrm{H}$ successfully identified $98 \%$ and $100 \%$ of samples at the species and genus levels, respectively.

Future studies could expand the number of taxa and analyze different parts of the plant for each taxon, to evaluate whether the matrix can actually affect the amplification preferences of one marker rather than another.

As regards the contaminants detected in the products, since many of them are unique to that product, we can deduce that it is possible that contamination occurred along the supply chain of the manufacturing company. For this reason, HTS analysis can be a method for controlling not only raw materials but also any contamination, which can be both a quality and food safety problem.

\subsection{Quantitative Ability of High-Throughput DNA-Sequencing}

In the scientific literature, there is a debate about the ability of HTS to provide quantitative identification. Lamb and colleagues interpreted the relative OTU abundance as the relative abundance of biomass [36]. The main obstacle concerns all the biases that occur during the analysis, such as DNA extraction, PCR and bioinformatics analysis [34]. In our previous study, we noticed that amplicon DNA metabarcoding efficacy could be biased by the PCR amplification step using "universal" markers, and the occurrence of bias during PCR amplification may cause the inaccurate estimation of quantities. Additionally, Krehenwinkel and colleagues found bias in differential amplification due to priming efficiency during PCR. They suggest using degenerate primers and/or target amplicons with high priming site conservation [37]. In general, the magnitude of difference between the estimated and true values of diversity and abundances vary considering both amplification efficiencies and primer bias, as demonstrated by Kelly and colleagues [38]. Our analysis shows that DNA metabarcoding has a relative quantitative ability, even if there are some biases in the identification of all species. Indeed, in our case, we reported the preferen- 
tial amplification of some taxa, depending on the primers selected [24,38]. Nevertheless, a relative quantification is achieved, as shown in Figure 3 and demonstrated with PCoA using Bray-Curtis dissimilarity metrics. Moreover, starting from a mixture of gDNA in the ITS2 marker, which is the best one in terms of species identification according to our study, we observed a more accurate quantification compared to the biomass mixture, thus suggesting that the DNA extraction phase could impair the yield of DNA from complex matrices. Nevertheless, using two DNA barcode regions allows overcoming one of the identified biases.

Drawing meaningful conclusions from HTS studies starting from complex matrices is a complex task and strictly depends on understanding the entire process underlying the experimental workflow. In future works, it may be useful to test different parts of the same plant, to verify whether extraction bias can affect the amplification of DNA by one marker rather than the other, both quantitatively and qualitatively. Furthermore, it would be advisable to test different processing levels of a food product, to evaluate the integrity of the DNA and assess whether it can affect the amplification capacity.

\section{Materials and Methods}

\subsection{Sampling of Herbal Teas and Assembling of Mock Mixtures}

Fifteen samples of commercial herbal teas (Table 2) from five different companies were collected from supermarkets.

In order to evaluate the ability of DNA metabarcoding to quantify the ingredients in herbal products, we set up an assay composed both of biomasses and genomic DNA of five plants in different proportions (Table 3). For these mock mixtures, medicinal plant species commonly used as raw material for herbal teas and food supplements were chosen Althaea officinalis (roots), Arnica montana (flowers), Ilex paraguariensis (leaves), Paullinia cupana (seeds) and Solidago virgaurea (aerial parts). As reported in several studies [39,40], the isolation of DNA can be challenging from some tissues, such as wood and roots. For this reason, different parts of the plant were collected: roots, flowers, leaves, seeds and aerial parts. To test for the difference of quantification of plants in correlation to the sequences obtained before or after the extraction and to identify any bias, these mock mixtures were created with both plant sample quantities expressed as weight of dry material (biomasses) and with different concentrations of genomic DNA (gDNA). In detail, for mock mixtures created by biomasses (QB_016, QB_017 and QB_018), plants were weighed and mixed to obtain the percentages expressed in Table 3 . The weights and proportions chosen are consistent with the normal formulation of herbal teas, also in correlation with possible contaminants.

Concerning mock mixtures created by gDNA (QG_019, QG_020 and QG_021), DNA was individually extracted from each dry plant, as indicated in the next section, and individually quantified using a Qubit Fluorometer 4.0 (Thermofisher, Monza, Italy). Each plant species was identified by DNA barcoding analysis. Finally, we prepared different dilutions according to the percentages described in Table 3 of each DNA extract and we composed the artificial mixtures starting from the DNA extracts.

\subsection{DNA Extraction and Quantification}

DNA extractions for herbal teas, positive control and mock mixtures were carried out using the commercial kit DNeasy PowerPlant (QIAGEN, Hilden, Germany), following the manufacturer's instructions. We started from $50 \mathrm{mg}$ of dry sample material that was homogenized via a mortar and liquid nitrogen; after lysis and wash steps, DNA was eluted in $50 \mu \mathrm{L}$ of elution buffer and samples were stored at $-20^{\circ} \mathrm{C}$. Three technical replicates of DNA extraction were created for each sample, and negative controls of extraction were created. Genomic DNA concentration was evaluated by a Qubit 4.0 Fluorometer (Thermofisher, Monza, Italy). DNA concentrations (ng/ $\mu \mathrm{L}$ ) for all samples are indicated in Supplementary Table S2. 


\subsection{Libraries' Preparation and Sequencing}

In order to improve the ability to identify all the ingredients at the species level, two universal markers of DNA barcoding were analyzed in this study: psbA-trnH and ITS2. ITS2 was selected as it was used in many DNA metabarcoding studies on plants and herbal teas [13,41,42], while $p s b A-t r n H$ was selected because it has a high intraspecific variability [43]. Amplicons were obtained using the same approach described by Bruno et al. [19] with an Illumina adapter (Supplementary Table S6) using puReTaq Ready-To-Go PCR beads (GE Healthcare Life Sciences, Monza, Italy), following the manufacturer's instructions in a $25 \mu \mathrm{L}$ reaction containing $1 \mu \mathrm{L} 10 \mu \mathrm{M}$ of each primer and up to $30 \mathrm{ng}$ of gDNA. PCR cycles consisted of an initial denaturation step for $5 \mathrm{~min}$ at $94{ }^{\circ} \mathrm{C}$, followed by 40 cycles of denaturation $\left(30 \mathrm{~s}\right.$ at $\left.94^{\circ} \mathrm{C}\right)$, annealing $\left(30 \mathrm{~s}\right.$ at $\left.56^{\circ} \mathrm{C}\right)$ and elongation $\left(1 \mathrm{~min}\right.$ at $\left.72{ }^{\circ} \mathrm{C}\right)$, and hence, a final elongation at $72^{\circ} \mathrm{C}$ for $10 \mathrm{~min}$. Amplicon DNA was checked for concentration by using a Qubit dsDNA HS Assay Kit (Invitrogen, Carlsbad, CA, USA) (Supplementary Table S2) and amplicon length was measured by comparison against QX DNA Size Marker using the Qiaxcel Automatic electrophoresis system (QIAGEN, Hilden, Germany). Samples were sequenced by IGA Technology Services (Udine, Italy). The sequencing was carried out on the MiSeq sequencing platform (Illumina, San Diego, CA, USA) with a paired-end approach $(2 \times 300 \mathrm{bp})$.

\subsection{Bioinformatic Analysis and Data Visualization}

Illumina reads were analyzed with QIIME2 (ver. 2020.8; https://qiime2.org/, accessed on 7 September 2021) [44]. After demultiplexing, primers were trimmed, and ITS2 sequences were filtered with a minimum length of 100 . Sequences were merged, dereplicated and chimaeras were removed via the de novo method [45]. OTU clustering was applied with a 1.0 similarity threshold. OTUs shared in at least two samples and with at least 250 sequences were kept. The taxonomic assignment of OTUs was carried out via BLAST [46], considering only reference sequences belonging to Viridiplantae rank (TaxID: 33090), adopting an identity of $97 \%$ and a coverage of $90 \%$. Taxa bar plots were generated with the QIIME2 dedicated plugin taxa (https:/ / github.com/qiime2/q2-taxa, accessed on 7 September 2021).

To explore the similarity existing between gDNA and biomass mock samples, a PCoA analysis was performed. A Bray-Curtis distance [47] was applied to define the similarity matrix, using the QIIME2 core-metrics plugin (https:/ / github.com/qiime2/q2-diversity, accessed on 7 September 2021).

Statistical differences were calculated by permutation-based ANOVA (PERMANOVA) functions of the beta-group-significance plugin [48], with 999 permutations, considering sample type categories. A PERMANOVA pairwise contrast was also performed.

For each company, waffle charts were generated with the PyWaffle Python package (https:/ / pywaffle.readthedocs.io/, accessed on 7 September 2021) based on the results obtained considering the marker percentage of assigned taxa declared in the labels for $p s b A-t r n H$ and ITS2 barcodes compared with the total percentage with both markers.

\section{Conclusions}

The authenticity of an herbal product is a major concern for consumers, producers, processors and food authorities. In this context, high-throughput DNA-sequencing technologies (HTS) allowed us to detect and identify the plant composition of herbal commercial teas. Although HTS technology has some critical aspects, such as the quality of the extracted DNA [8] or the relative ability to quantify all the ingredients, this study showed the value of the application of HTS analysis for a quality control tool and routine monitoring analysis, from the characterization of the raw ingredients to the final processed products. Furthermore, the use of a multi-marker approach has allowed identifying a greater number of species within a sample, and it is therefore advisable, for future work, to use more than one marker to increase the identification rate. In conclusion, this tool can be applied to a wider range of botanicals to improve the traceability of all products. 
HTS analysis has such a sensitivity that it can find even small quantities of plants that can be potentially poisonous or harmful to health, so this tool has great potential in quality and safety control in the field of herbal teas. For this reason, it is desirable to implement this analysis by EFSA or other control agencies. As these agencies take long periods to implement analysis, it may be appropriate for companies to start using these tools for preventive control of their supply chain and their products, before it becomes mandatory.

Supplementary Materials: The following are available online at https: / www.mdpi.com/article / 10.3390/plants10102120/s1 Table S1: dataset for bar charts ((Figures 1 and 2) and waffle charts (Figure 3) are available in the .xls file, Table S2: gDNA concentrations, Table S3: dataset of HTS sequencing percentages compared to expected samples, Table S4: beta-diversity analysis of ITS2 samples compared to expected samples, Table S5: beta-diversity analysis of psbA-trnH samples compared to expected samples, Table S6: primer sequences.

Author Contributions: Conceptualization, J.F. and V.M.; methodology and validation, J.F. and G.A.; data curation G.A., J.F. and V.M.; writing-original draft preparation, J.F., V.M., G.A. and A.B.; writing-review and editing J.F., V.M., G.A. and A.B.; supervision M.L.; project administration, F.D.M. and M.L. All authors have read and agreed to the published version of the manuscript.

Funding: This research was funded by the Italian Ministry of University and Research through the grant 'Dipartimenti di Eccellenza, 2017' within the CHRONOS project.

Data Availability Statement: Data are available at the EBI metagenomics portal (https:/ /www.ebi. ac.uk/metagenomics/), accessed on 7 September 2021, study ID: PRJEB47866.

Acknowledgments: The authors are indebted to F. Scrivo for advice and support.

Conflicts of Interest: FEM2-Ambiente s.r.l. provided support in the form of a salary for authors J.F., V.M. and F.D.M. The company only provided financial support in the form of research materials. The funders had no role in the design of the study; in the collection, analyses, or interpretation of data; in the writing of the manuscript, or in the decision to publish the results.

\section{References}

1. Lu, Z.; Rubinsky, M.; Babajanian, S.; Zhang, Y.; Chang, P.; Swanson, G. Visualization of DNA in highly processed botanical materials. Food Chem. 2018, 245, 1042-1051. [CrossRef]

2. Smith, T.; Kawa, K.; Eckl, V.; Morton, C.; Stredney, R. Herbal Supplement Sales in US Increase 7.7\% in 2016. HerbalGram 2017, 115, 56-65.

3. Marieschi, M.; Torelli, A.; Poli, F.; Sacchetti, G.; Bruni, R. RAPD-based method for the quality control of Mediter-ranean oregano and its contribution to pharmacognostic techniques. J. Agric. Food Chem. 2009, 57, 1835-1840. [CrossRef]

4. Lupien, J.R. Food Quality and Safety: Traceability and Labeling. Crit. Rev. Food Sci. Nutr. 2005, 45, 119-123. [CrossRef]

5. Anthoons, B.; Karamichali, I.; Schrøder-Nielsen, A.; Drouzas, A.D.; de Boer, H.; Madesis, P. Metabarcoding reveals low fidelity and presence of toxic species in short chain-of-commercialization of herbal products. J. Food Compos. Anal. 2021, 97, 103767. [CrossRef]

6. Nithaniyal, S.; Vassou, S.L.; Poovitha, S.; Raju, B.; Parani, M. Identification of species adulteration in traded medicinal plant raw drugs using DNA barcoding. Genome 2017, 60, 139-146. [CrossRef] [PubMed]

7. Mosa, K.A.; Soliman, S.; El-Keblawy, A.; Ali, M.A.; Hassan, H.A.; Tamim, A.A.; Al-Ali, M.M. Using DNA bar-coding to detect adulteration in different herb-al plant-based products in the United Arab Emirates: Proof of concept and validation. Recent Pat. Food Nutr. Agric. 2018, 9, 55-64. [CrossRef]

8. Grazina, L.; Amaral, J.S.; Mafra, I. Botanical origin authentication of die-tary supplements by DNA-based approaches. Compr. Rev. Food Sci. Food Saf. 2020, 19, 1080-1109. [CrossRef] [PubMed]

9. Cornara, L.; Smeriglio, A.; Frigerio, J.; Labra, M.; Di Gristina, E.; Denaro, M.; Mora, E.; Trombetta, D. The problem of misidentification between edible and poisonous wild plants: Reports from the Mediterranean area. Food Chem. Toxicol. 2018, 119, 112-121. [CrossRef] [PubMed]

10. Garzo, C.F.; Gómez, P.P.; Barrasa, A.B.; Martínez, R.A.; Ramírez, R.F.; Ramón, F.R. Cases of neurological symptoms associated with star anise consump-tion used as a carminative. An. Esp. Pediatr. 2002, 57, 290-294.

11. Wiedenfeld, H. Plants containing pyrrolizidine alkaloids: Toxicity and problems. Food Addit. Contam. Part A 2011, $28,282-292$. [CrossRef] [PubMed]

12. Raclariu, A.C.; Paltinean, R.; Vlase, L.; Labarre, A.; Manzanilla, V.; Ichim, M.C.; de Boer, H. Comparative au-thentication of Hypericum perforatum herbal products using DNA metabarcoding, TLC and HPLC-MS. Sci. Rep. 2017, 7, 1291. [CrossRef] [PubMed] 
13. Raclariu, A.C.; Mocan, A.; Popa, M.O.; Vlase, L.; Ichim, M.C.; Crisan, G.; de Boer, H. Veronica officinalis prod-uct authentication using DNA metabarcoding and HPLC-MS reveals widespread adulteration with Veronica chamaedrys. Front. Pharmacol. 2017, 8, 378. [CrossRef] [PubMed]

14. Lo, Y.-T.; Shaw, P.-C. DNA-based techniques for authentication of processed food and food supplements. Food Chem. 2018, 240, 767-774. [CrossRef] [PubMed]

15. Galimberti, A.; Casiraghi, M.; Bruni, I.; Guzzetti, L.; Cortis, P.; Berterame, N.M.; Labra, M. From DNA barcoding to personalized nutrition: The evolution of food traceability. Curr. Opin. Food Sci. 2019, 28, 41-48. [CrossRef]

16. Galimberti, A.; Labra, M.; Sandionigi, A.; Bruno, A.; Mezzasalma, V.; De Mattia, F. DNA Barcoding for Minor Crops and Food Traceability. Adv. Agric. 2014, 2014, 831875. [CrossRef]

17. Hellberg, R.S.; Hernandez, B.C.; Hernandez, E.L. Identification of meat and poultry species in food products using DNA barcoding. Food Control 2017, 80, 23-28. [CrossRef]

18. De Mattia, F.; Bruni, I.; Galimberti, A.; Cattaneo, F.; Casiraghi, M.; Labra, M. A comparative study of different DNA barcoding markers for the iden-tification of some members of Lamiacaea. Food Res. Int. 2011, 44, 693-702. [CrossRef]

19. Bruno, A.; Sandionigi, A.; Agostinetto, G.; Bernabovi, L.; Frigerio, J.; Casiraghi, M.; Labra, M. Food Tracking Perspective: DNA Metabarcoding to Identify Plant Composition in Complex and Processed Food Products. Genes 2019, 10, 248. [CrossRef]

20. Haynes, E.; Jimenez, E.; Pardo, M.A.; Helyar, S.J. The future of NGS (Next Generation Sequencing) analysis in testing food authenticity. Food Control 2019, 101, 134-143. [CrossRef]

21. Shokralla, S.; Spall, J.L.; Gibson, J.F.; Hajibabaei, M. Next-generation sequencing technologies for environmental DNA research. Mol. Ecol. 2012, 21, 1794-1805. [CrossRef]

22. Elbrecht, V.; Leese, F. Can DNA-based ecosystem assessments quantify species abundance? Testing primer bias and biomassSequence relationships with an innovative metabarcoding protocol. PLoS ONE 2015, 10, e0130324. [CrossRef]

23. Frigerio, J.; Pellesi, R.; Mezzasalma, V.; De Mattia, F.; Galimberti, A.; Lambertini, F.; Suman, M.; Zanardi, S.; Leporati, A.; Labra, M Development of a DNA Barcoding-Like Approach to Detect Mustard Allergens in Wheat Flours. Genes 2019, 10, 234. [CrossRef]

24. Staats, M.; Arulandhu, A.J.; Gravendeel, B.; Holst-Jensen, A.; Scholtens, I.; Peelen, T.; Prins, T.W.; Kok, E. Advances in DNA metabarcoding for food and wildlife forensic species identification. Anal. Bioanal. Chem. 2016, 408, 4615-4630. [CrossRef]

25. CBOL Plant Working Group; Hollingsworth, P.M.; Forrest, L.L.; Spouge, J.L.; Hajibabaei, M.; Ratnasingham, S.; van der Bank, M.; Chase, M.W.; Cowan, R.S.; Erickson, D.L.; et al. A DNA barcode for land plants. Proc. Natl. Acad. Sci. USA 2009, 106, 12794-12797. [CrossRef]

26. Chen, S.; Yao, H.; Han, J.; Liu, C.; Song, J.; Shi, L.; Zhu, Y.; Ma, X.; Gao, T.; Pang, X.; et al. Validation of the ITS2 Region as a Novel DNA Barcode for Identifying Medicinal Plant Species. PLoS ONE 2010, 5, e8613. [CrossRef]

27. Kuzmina, M.L.; Braukmann, T.W.A.; Fazekas, A.J.; Graham, S.W.; Dewaard, S.L.; Rodrigues, A.; Bennett, B.A.; Dickinson, T.A.; Saarela, J.M.; Catling, P.M.; et al. Using herbarium-derived DNAs to assemble a large-scale DNA barcode library for the vascular plants of Canada1. Appl. Plant Sci. 2017, 5, 1700079. [CrossRef] [PubMed]

28. Yao, H.; Song, J.; Liu, C.; Luo, K.; Han, J.; Li, Y.; Pang, X.; Xu, H.; Zhu, Y.; Xiao, P.; et al. Use of ITS2 Region as the Universal DNA Barcode for Plants and Animals. PLoS ONE 2010, 5, e13102. [CrossRef] [PubMed]

29. Kress, W.J.; Erickson, D.L. A Two-Locus Global DNA Barcode for Land Plants: The Coding rbcL Gene Comple-ments the Non-Coding trnH-psbA Spacer Region. PLoS ONE 2007, 2, e508. [CrossRef] [PubMed]

30. Stefanni, S.; Stanković, D.; Borme, D.; De Olazabal, A.; Juretić, T.; Pallavicini, A.; Tirelli, V. Multi-marker metabarcoding ap-proach to study mesozooplankton at basin scale. Sci. Rep. 2018, 8, 12085. [CrossRef]

31. Da Silva, L.P.; Mata, V.A.; Lopes, P.B.; Pereira, P.; Jarman, S.N.; Lopes, R.J.; Beja, P. Advancing the integration of multi-marker metabarcoding data in dietary analysis of trophic generalists. Mol. Ecol. Resour. 2019, 19, 1420-1432. [CrossRef]

32. Arulandhu, A.J.; Staats, M.; Hagelaar, R.; Peelen, T.; Kok, E.J. The application of multi-locus DNA metabarcoding in traditional medicines. J. Food Compos. Anal. 2019, 79, 87-94. [CrossRef]

33. Deagle, B.E.; Jarman, S.N.; Coissac, E.; Pompanon, F.; Taberlet, P. DNA metabarcoding and the cytochrome c oxi-dase subunit I marker: Not a perfect match. Biol. Lett. 2014, 10, 20140562. [CrossRef]

34. Piñol, J.; Senar, M.A.; Symondson, W.O. The choice of universal primers and the characteristics of the species mixture determine when DNA metabarcoding can be quantitative. Mol. Ecol. 2019, 28, 407-419. [CrossRef]

35. Lv, Y.-N.; Yang, C.-Y.; Shi, L.-C.; Zhang, Z.-L.; Xu, A.-S.; Zhang, L.-X.; Li, X.-L.; Li, H.-T. Identification of medicinal plants within the Apocynaceae family using ITS2 and psbA-trnH barcodes. Chin. J. Nat. Med. 2020, 18, 594-605. [CrossRef]

36. Lamb, P.D.; Hunter, E.; Pinnegar, J.; Creer, S.; Davies, R.G.; Taylor, M.I. How quantitative is metabarcoding: A meta-analytical approach. Mol. Ecol. 2018, 28, 420-430. [CrossRef]

37. Krehenwinkel, H.; Kennedy, S.R.; Rueda, A.; Lam, A.; Gillespie, R.G. Scaling up DNA barcoding-Primer sets for simple and cost efficient arthropod systematics by multiplex PCR and Illumina amplicon sequencing. Methods Ecol. Evol. 2018, 9, 2181-2193. [CrossRef]

38. Kelly, R.P.; Shelton, A.O.; Gallego, R. Understanding PCR processes to draw meaningful conclusions from en-vironmental DNA studies. Sci. Rep. 2019, 9, 12133. [CrossRef]

39. Paranaiba, R.T.; Carvalho, C.B.; Paiva, R.S.; Trindade, B.R.; Barros, M.G.; Souza, E.P.; Gontijo, A.B.; Silveira, D. DNA from wood-A simple approach facing a challenging matrix-A preliminary study. Forensic Sci. Int. 2020, 314, 110371. [CrossRef] 
40. Lu, Y.; Jiao, L.; He, T.; Zhang, Y.; Jiang, X.; Yin, Y. An optimized DNA extraction protocol for wood DNA barcoding of Pterocarpus erinaceus. IAWA J. 2020, 41, 644-659. [CrossRef]

41. Biella, P.; Tommasi, N.; Akter, A.; Guzzetti, L.; Klecka, J.; Sandionigi, A.; Labra, M.; Galimberti, A. Foraging strategies are maintained despite workforce reduction: A multidisciplinary survey on the pollen collected by a social pollinator. PLOS ONE 2019, 14, e0224037.

42. Richardson, R.T.; Lin, C.H.; Sponsler, D.B.; Quijia, J.O.; Goodell, K.; Johnson, R.M. Application of ITS2 metabar-coding to determine the provenance of pollen collected by honey bees in an agroecosystem. Appl. Plant Sci. 2015, 3, 1400066. [CrossRef] [PubMed]

43. Bolson, M.; Smidt ED, C.; Brotto, M.L.; Silva-Pereira, V. ITS and trnH-psbA as efficient DNA barcodes to identify threatened commercial woody angiosperms from southern Brazilian Atlantic rainforests. PLoS ONE 2015, 10, e0143049. [CrossRef] [PubMed]

44. Bolyen, E.; Rideout, J.R.; Dillon, M.R.; Bokulich, N.A.; Abnet, C.C.; Al-Ghalith, G.A.; Alexander, H.; Alm, E.J.; Arumugam, M.; Asnicar, F; et al. Reproducible, interactive, scalable and extensible microbiome data science using QIIME 2. Nat. Biotechnol. 2019, 37, 852-857. [CrossRef]

45. Rognes, T.; Flouri, T.; Nichols, B.; Quince, C.; Mahé, F. VSEARCH: A versatile open source tool for metagenomics. PeerJ 2016, 4, e2584. [CrossRef]

46. Altschul, S.F.; Gish, W.; Miller, W.; Myers, E.W.; Lipman, D.J. Basic local alignment search tool. J. Mol. Biol. 1990, 215 , 403-410. [CrossRef]

47. Lozupone, C.; Lladser, M.E.; Knights, D.; Stombaugh, J.; Knight, R. UniFrac: An effective distance metric for microbial community comparison. ISME J. 2011, 5, 169-172. [CrossRef] [PubMed]

48. Anderson, M.J. A new method for non-parametric multivariate analysis of variance. Austral. Ecol. 2001, 26, 32-46. 